\title{
ПРОГНОЗУВАННЯ СТУПЕНЯ УРАЖЕННЯ КІСТКОВО ТКАНИНИ НА ОСНОВІ АНАЛІЗУ ДАНИХ ОРТОПАНТОМОГРАФІ ТА ЕХООСТЕОМЕТРІ ЩЕЛЕП У ПАЦІЄНТІВ, ХВОРИХ НА ЦУКРОВИЙ ДІАБЕТ ІІ ТИПУ
}

\section{СМ. М. Якимець \\ ДВНЗ «Тернопільський державний медичний університет імені І. Я. Горбачевського МОЗ України»}

РЕЗЮМЕ. В статті розглянуто можливість прогнозування ступеня ураження кістково тканини на основі аналізу даних ортопантомографі та ехоостеометрі щелеп у пацієнтів, хворих на цукровий діабет II типу. Поєднане застосування цих двох методів дослідження дозволяє оптимально вибрати у клініці необхідні лікувальні заходи для хворих 3 цукровим діабетом II типу та пародонтитом.

КЛЮЧОВІ СЛОВА: цукровий діабет, пародонт, мінеральна щільність кістково тканини, ортопантомограма.

Вступ. Цукровий діабет (ЦД) і захворювання пародонта $є$ поширеними хронічними захворюваннями в багатьох кра нах світу. ЦД II типу зустрічається майже в 20 разів частіше, ніж інсулінозалежний діабет, а його частка серед інших форм досягає 85-90\% [1]. На даний час фактична поширеність інсулінонезалежного типу ЦД в 2-3 рази перевищує його реєстровану поширеність. Порушення гормонального балансу у хворих на ЦД призводить до порушення мінералізаці кісток внаслідок змін фосфорно-кальцієвого балансу через недостатність кальцію, дефіцит якого $є$ одним із чинників остеопорозу [2]. Також ЏД впливає на мінеральний обмін речовин як в цілому організмі, так і безпосередньо в кістковій тканині щелеп [3]. За даними літератури встановлено, що ЦД, особливо II типу, супроводжується гіперкальційурією та ранніми трабекулярними втратами мінерально щільності кістково тканини. Порушуються процеси кісткового ремоделювання і виникає так званий вторинний остеопороз. До найбільших змін схильні альвеолярний відросток, тіло нижньо щелепи і суглобовий горбик скронево кістки. Достовірне зниження мінерально насиченості спостерігалося лише в альвеолярному відростку в ділянці різців [4].

За останні роки досить широко використовують неінвазивні методи дослідження стану кістково тканини за допомогою ультразвуку. Відомо, що швидкість проведення ультразвуку відображає еластичні властивості кістково тканини і об'ємну мінеральну щільність. Вимірюваний при цьому декремент послаблення ультразвукових хвиль в об'єкті асоціюється з густиною композиці і структурою трабекулярно кістки [5; 6].

Мета дослідження - підвищення ефективності комплексно оцінки стану тканин пародонта у хворих ЦД II типу шляхом проведення морфометрично оцінки ортопаномограм та ехоостеометрі .

Матеріали та методи дослідження. Для дослідження структурно-функціонального стану кістково тканини і тканин пародонта ми використовували методи ехоостеометрі та ортопаномографі .
Для кількісно оцінки стану пародонта нами було проведено аналіз 6-ти ортопантомограм (ОПТГ) практично здорових осіб із нормальним стоматологічним статусом (контрольна група), а також 24-х ОПТГ (12 пацієнтів із тривалістю захворювання на ЦД менше 10 років, 12 - більше 10 років), хворих на ЦД, ускладнений пародонтитом. При цьому вимірювали висоту коронки (a), висоту шийки зуба (b) і довжину кореня (c), а також довжину кореневого каналу (d) та відстань від анатомічно до рентгенологічно верхівки (е) з урахуванням облітераці кореневого каналу. За вимірюваними показниками вираховували х співвідношення [7].

Ехоостеометрію проводили за допомогою ехоостеометра “ЕОМ - 01 ц", Швидкість поширення ультразвуку в кістці, яка розташована між датчиками, розраховували за формулою:

$$
\mathrm{C}=\mathrm{L} / \mathrm{t} \cdot 10^{4} \text {, }
$$

де C - швидкість поширення ультразвуку в кістці,

$\mathrm{L}$ - товщина досліджувано кістки,

$\mathrm{t}$ - час проходження ультразвуку через кістку.

Статистичну обробку отриманих результатів здійснювали методом варіаційно статистики з використанням програми Microsoft Excel. Визначали середнє значення (М), стандартне відхилен-

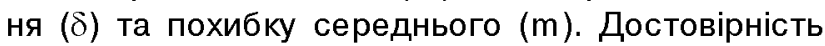
оцінювали за коефіцієнтом Стьюдента (t).

Результати та х обговорення. Для діагностично оцінки структурно-Функціонального стану щелеп пацієнтів було проведено аналіз ОПТГ в ділянках різних груп зубів (рис.1-4).

У хворих із ЦД та пародонтитом на ОПТГ спостерігали нерівномірну деструкцію кортикально пластинки в ділянці верхівок міжкоміркових перегородок та наявність вогнищ остеопорозу у вигляді зон просвітлення. Відбувалася зміна структури кісткових балок у напрямку формування великопетлистого рисунка. Відмічалося також розширення періодонтально щілини. Резорбція міжальвеолярних перегородок сягала до 1/3 довжини кореня, що клінічно відповідало । ступеню пародонтиту. 
Огляди літератури, оригінальні дослібження, погляд на проблему

Відмічалося зменшення співвідношень a/b (в середньому на (55-60) \%) і d/e (в середньому на (43-47) \%), співвідношення b/c, навпаки, збільшувалося (на (155-170) \%), а співвідношення а/с суттєво не змінювалося, хоча можна було спостерігати тенденцію до його зниження у фронтальній групі зубів і деякого підвищення в ділянці молярів. Зменшення a/b i одночасне збільшення b/c може бути пояснено атрофічними змінами міжальвеолярних перегородок. Зниження співвідношення d/е при цьому відбувалося за рахунок облітераці кореневого каналу. Тенденція до зниження показника а/с у фронтальній групі зубів виникала внаслідок вторинно деформаці зубного ряду. Підвищення цього показника у ділянці молярів пов'язане з оголенням шийки зуба при збереженні розмірів висоти $\mathrm{x}$ коронки.
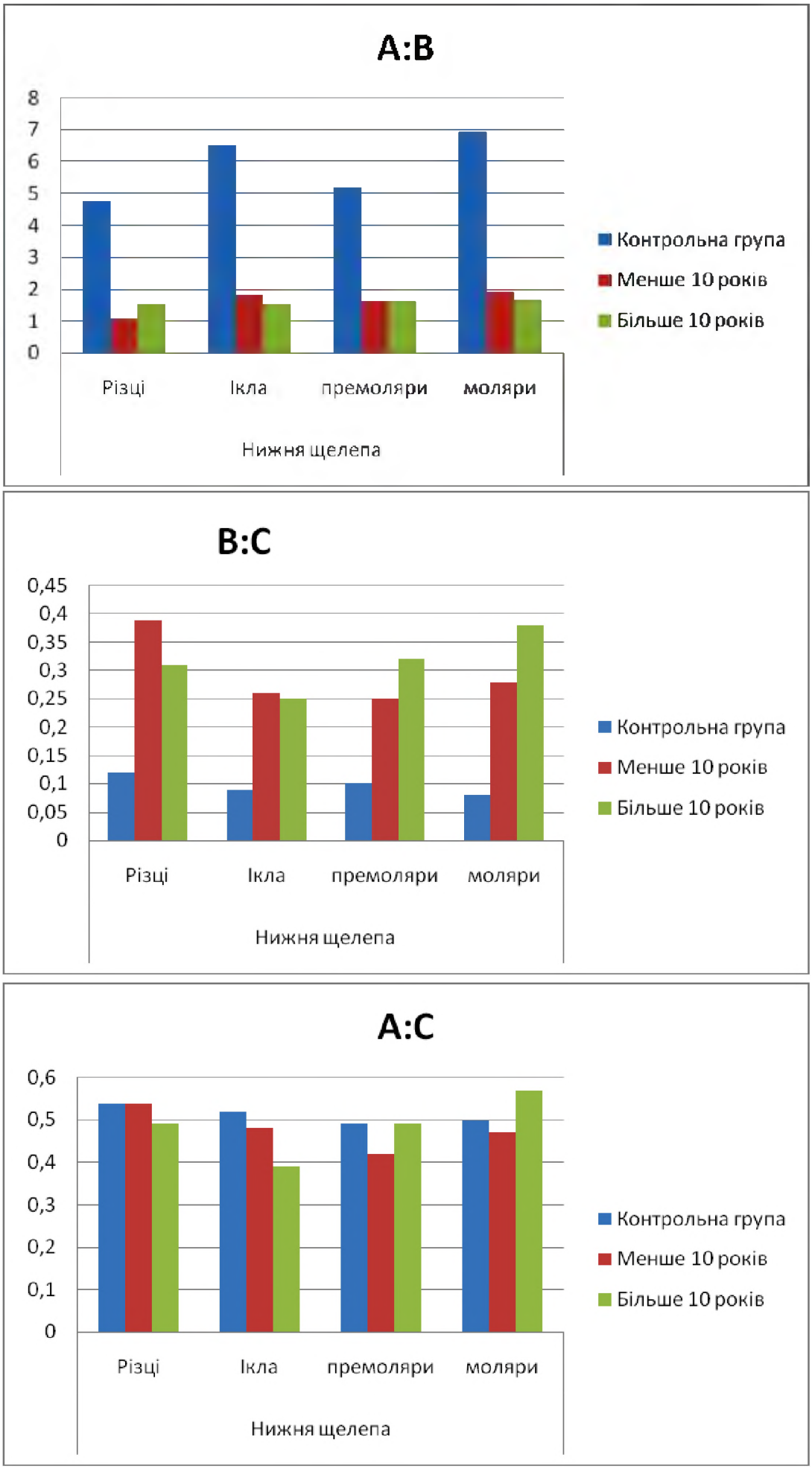

Рис. 1. Морфометричні показники ОПТГ у хворих на ЦД II типу у віці від 40 до 55 років. А:В - співвідношення між висотою коронки зуба і шийки.
Рис. 2. Морфометричні показники ОПТГ у хворих на ЦД ІІ типу у віці від 40 до 55 років. В:C - співвідношення між висотою шийки і довжиною кореня; 


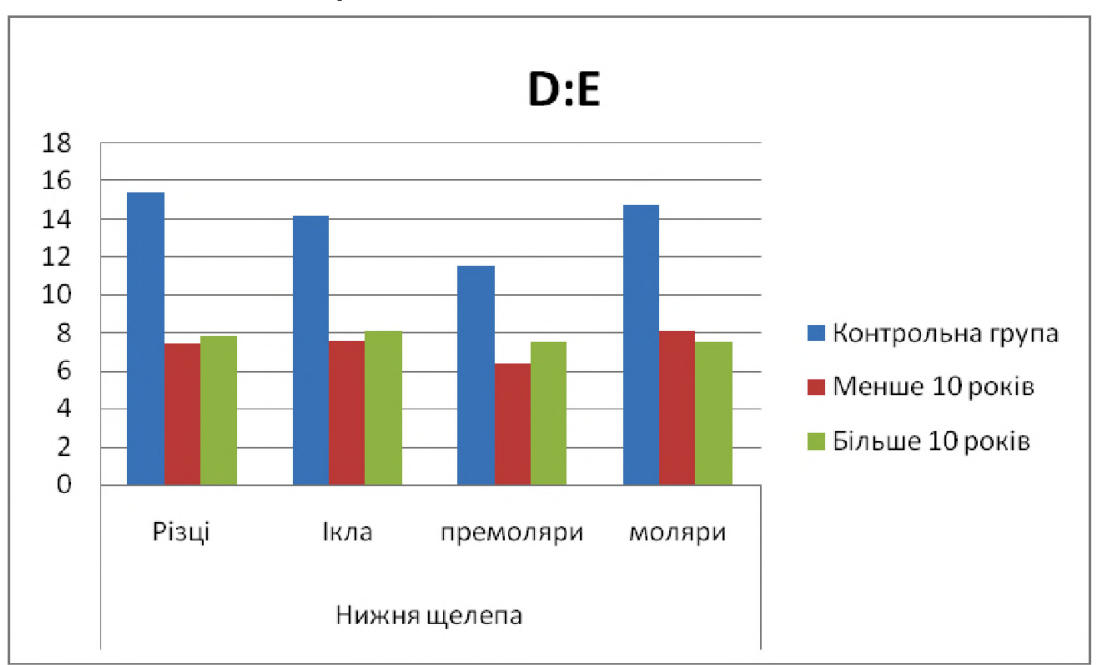

Рис. 4. Морфометричні показники ОПТГ у хворих на џД ІІ типу у віці від 40 до 55 років. D:E - співвідношення між довжиною кореневого каналу і відстанню від анатомічно до рентгенологічно верхівки.
У хворих з тривалим перебігом ЦД (більше 10 років) відмічено стабілізацію кількісних характеристик, хоча по окремих зубах можна було спостерігати $x$ прогресування. Це може бути пояснено тим, що при подальшому прогресуванні процесу настає втрата зубів, що й відмічалося на більшості ортопантомограм у дано частини пацієнтів. Візуальний аналіз ортопантомограм хворих із тривалим перебігом цукрового діабету дозволив підтвердити поглиблення процесів вертикально резорбці кістково тканини 3 нерівномірною деструкцією кортикально пластинки в ділянці верхівок міжкоміркових перегородок та виникненням вогнищ остеопорозу. Резорбція міжальвеолярних перегородок сягала 1/2 довжини кореня, що клінічно відповідало II ступеню пародонтиту. Запропонована нами кількісна оцінка ортопантомограм проста у використанні і, водночас, дає можливість об'єктивно підійти до діагностики пародонтиту як ускладнення цукрового діабету й як наслідку впливу інших етіологічних факторів.

Щільність кістково тканини у практично здорових паціентів контрольно групи за даними ехоостеометрі рівномірна і практично однакова у всіх ділянках право і ліво сторін нижньо щелепи. В нормі показник часу проходження ультразвуково хвилі через кістки нижньо щелепи в середньому складав $(12,58 \pm 0,41)$ мкс 3 відповідним $\mathrm{C}=(800,41 \pm 24,42)$.

При обстеженні хворих на цукровий діабет II типу спостерігалося досить відчутне i, водночас, відносно рівномірне збільшення часу проходження ультразвуку через кістки нижньо щелепи (рис. 5). Приріст часу при цьому складав до 15-17\% (при середньому значенні в $((14,67 \pm 0,27))$ мкс) з відповідним зниженням до 15-17\% С (при його середньому значенні в $(687,43 \pm 12,64))$.

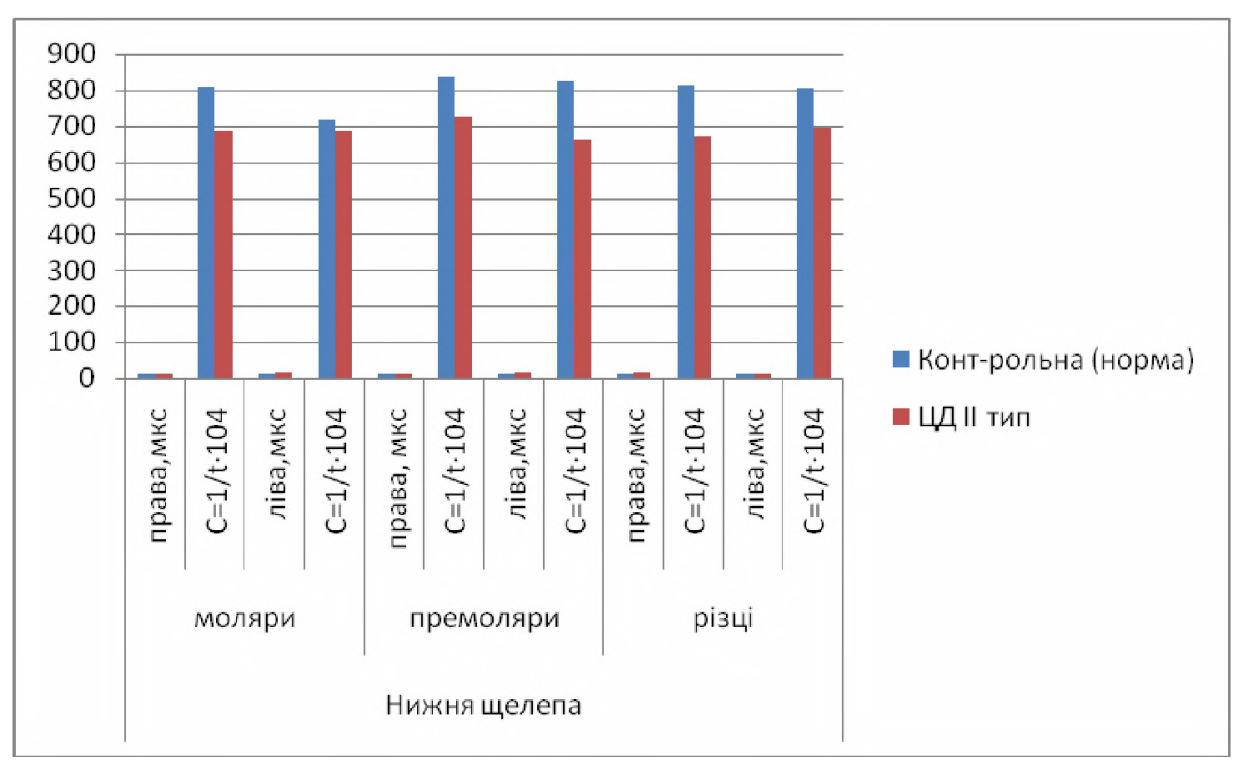

Рис. 5. Стан щільності кістково тканини нижньо щелепи пацієнтів за даними ультразвуково ехоостеометрі . 


\title{
Оеляди літератури, ориаінальні дослідження, погляд на проблему
}

Отримані в результаті обстеження даного контингенту пацієнтів показники свідчили про розвиток явищ остеосклерозу в кістках нижньо щелепи у хворих на ЦД, який не завжди є характерним для генералізованого пародонтиту. У результаті прогресування пародонтиту відбувається зменшення об'єму кістково тканини, що випливає $з$ аналізу морфометричних показників, водночас, ехоостеометричні показники свідчили про розвиток склеротичних явищ, що говорить про компенсаторні механізми.

Тому дані ехоостеометричних досліджень можуть використовуватися як додатковий критерій при діагностиці пародонтиту і визначення ступеня процесів ремоделювання і, в кінцевому результаті, про прогноз клінічного перебігу пародонтиту у хворих на ЦД.

Висновки. 1. На даний час одним із основних методів діагностики захворювань пародонта $\mathbf{E}$ ортопантомографія, яка дає можливість виявити ознаки пародонтиту - резорбційні та деструктивні зміни в кістках альвеолярних відростків, зокрема, запропоновані морфометричні індекси.

2. Додатковим і відносно простим методом може бути ехоостеометрія, яка дозволяє визначити стан кістково тканини щелеп у пародонтологічних хворих з метою діагностики патологічних змін (чи це превалює остеорезорбція, чи - остеосклероз).

3. Поєднане застосування цих двох методів дослідження дозволяє оптимально вибрати у клініці необхідні лікувальні заходи для хворих з цукровим діабетом II типу та пародонтитом.

4. Дані дослідження можуть бути застосовані в практичній роботі лікарями стоматологічних кабінетів, а також при проведенні наукових спостережень, що стосуються морфофункціонально перебудови пародонта при його патологічних змінах.

Перспективи подальш их досліджень. У подальшому слід вивчити ехоостеометричні та рентгеноморфометричні показники у пародонтологічних хворих із цукровим діабетом I типу.

\section{ЛІТЕРАТУРА}

1. Janka $H$. U. Epidemiology of diabetes mellitus: Prevalence, incidence, pathogenesis, and prognosis / H. U. Janka, D. Michaelis //Z. Arztl. Fortbild. Qualitatssich. 2002. - Vol. 96, № 3. - P. 159-165.

2. Лікування остеопорозу препаратами кальцію у хворих на цукровий діабет / В. М. Хворостинка, В. О. Федоров, О. В. Сокруто [та ін.] // Проблеми остеологі. 2007. - T. 9, № 2 - 3. - С. 85-87.

3. НигматовР. Н. Состояние костнойтканипародонта у больных с заболеваниями внутренних органов / Р. Н. Нигматов, Н. Юлдашева, Н. Р. Нигматова // Вісник стоматологі . - 2008. - № 1. - С. 59-62.

4. Звигинцев М. А. Стоматологическая реабилитация больных сахарным диабетом : автореф. дис. канд. мед.

наук : спец. 14.01.22. "Стоматология" / М. А. Звигинцев. Омск, 1998. - 43 c.

5. Поворознюк В. В. Возрастные аспекты структурнофункционального состояния костной ткани населения Украины / В. В. Поворознюк // Остеопороз и остеопатии. - 2000. - № 1. - С. 15-22.

6. Ковальчук Л. Я. Проблеми остеопорозу / за ред. проф. Л. Я. Ковальчука. - Тернопіль : Укрмедкнига, 2002. $-446 \mathrm{c}$.

7. І. Є. Герасимюк Оцінка стану пародонта у хворих на цукровий діабет за результатами кількісного аналізу ортопантомограм / І. Є. Герасимюк, М.М.Якимець, Л. Я. Федоюк // Вісник морфологі . - 2010. - Т.16, № 4. С. $857-861$.

\section{PROGNOSIS OF BONE TISSUE STAGE OF DESTRUCTION ON THE BASIS OF ANALYSES OF PANORAMIC X-RAY DATA AND ECHOOSTEOMETRIC DATA OF JAWS IN PATIENTS WITH DIABETES MELLITUS TYPE II}

\author{
@M. M. Yakymets \\ SHEI «Ternopil State Medical University by I.Ya. Horbachevsky of MPH of Ukraine» \\ SUMMARY. In this article we analyzed the ability to predict the degree of destruction of bone tissue by analyzing data of \\ panoramic $x$-ray and echoosteometric data in patients with diabetes mellitus type II. The combined use of these two methods \\ of research allows to optimally select the required hospital treatment measures for patients with type II diabetes and periodontitis. \\ KEY WORDS: diabetes mellitus, periodontium, bone mineral density, panoramic $x$-ray.
}

